\title{
Students' Mathematics Reasoning Ability Reviewing from Learning Interest of Students at SMPN 16 Pekanbaru
}

\author{
Dewi Yuliani
}

Universitas Riau, INDONESIA

\section{ARTICLE'S \\ INFORMATION}

\section{Article history:}

Received: Nov-27-2021

Reviewed: Dec-01-2021

Accepted: Dec-24-2021

Keywords: Learning

Interest, Reasoning Ability, Social Arithmetic

\begin{abstract}
This research is motivated by the existence of facts in the field which show the low mathematical.reasoning skills found in students at SMP Negeri 16 Pekanbaru. One thing that students must master to achieve learning goals is mathematical reasoning abilities. In other words, students can use mathematics as a reasoning tool both in learning mathematics in class and everyday life. This research aims to determine the difference between students' mathematical reasoning abilities and low learning interest. Good student learning interest will make students happy to learn mathematics without coercion, with good learning interest will affect students' mathematical reasoning abilities. Mathematical reasoning abilities can be improved through increasing student interest in learning. This research is a qualitative descriptive study, the population in this study were all eighth-grade students of the 2020/2021 academic year. The sample taken was class VIII.2 using a random cluster. Data collection techniques and research instruments are tests of mathematical reasoning abilities on quadrilateral material, questionnaires in questionnaire sheets for learning interests, and interviews. Based on the results of data analysis, it can be concluded that: 1) There are differences in mathematical reasoning abilities between students who have high learning interests. 2) There are differences in mathematical reasoning abilities between students with low interest in learning.
\end{abstract}

\section{Corresponding address:}

Dewi Yuliani,

E-mail: dewiyuliani1997@gmail.com

\section{INTRODUCTION}

Change era that always follow developments, knowledge, and technology, the complexity of life's problems according to reliable and competent human resources in global competition. In addition to rapid development, changes also occur rapidly. To support this, it is necessary to have the ability to acquire, process, and utilize existing resources so that they can survive in conditions that are always changing, uncertain and competitive. Progress can be realized in life if there is mastery of science knowledge and various fields. So to upgrade quality science knowledge and technology needed, there is education [1].

Broadly, education is defined as life. Education is effort consciously which i done in realizing process learning so that students actively can develop potential himself [2]. Meanwhile in the narrow sense. Education is the process occurrence interaction between a teacher with students in an environment school [3]. Teaching is a process of occurring two activities between parties, teacher, and students, for achievement communication well in improving process learning inclass teaching in detail, according to Law Republic Indonesia Number 20 the Year 2003 about System Education National Article 1 paragraph 1. So that participants students in a to develop potential themselves to have spiritual solid religious, controlling self, personality, intelligence, morals noble and. Skills. which are needed himself, society, nation and country [4]. 
Education is something important for the progress of a country, where education is the main factor in intellectual change for humans and the academic life of the nation. Education is a planned effort in realizing the learning process so that students actively develop their potential for intelligence, self-control, knowledge, and skills [5]. The purpose of education is to develop the potential of students to achieve human beings who believe, fear God Almighty, and have a noble character, are knowledgeable, creative, independent, and responsible [6].

As for realizing the goals of education, it is necessary to increase the mastery and development of knowledge. Then to achieve mastery and development of science, there must be an education system that always carries out a renewal. Renewal of the education system requires a strategy that can build national education as stated in Law Number 20 of 2003, including: "(1) Development and implementation of competency-based curriculum, (2) educational and dialogical learning process, (3) professional improvement of educators and education staff, (4) provision of educational learning facilities, (5) implementation of education management autonomy, (6) implementation of supervision in the education system national and so on [7].

The education system in Indonesia is expected to optimally achieve the national education goals desired by law so that the next generation will not have difficulty competing in the current era of globalization. Because indeed, education in our country cannot be seen apart from the significant changes that occur due to global currents associated with various thoughts of community leaders who live in the global era [8].

Mathematics is a discipline that can underlie modern technological development because mathematics itself has a very important role in various other sciences and greatly influences the power of human thought [9]. Mathematics is very important in the education system of all countries in the world. Governments that ignore mathematics education as a top priority will be left behind in all fields, compared to other countries that emphasize mathematics as an important subject [10].

Mathematics is the most basic science and plays an important role in developing science and technology. This is based on mathematics's ability to develop logical, systematic, and critical thinking. Mathematics is a science obtained through reasoning because the learning process of mathematics aims for students to use reasoning in solving patterns and traits, using mathematical manipulation to make generalizations, compiling evidence, explaining ideas and statements from mathematics [11]. Mathematics is a discipline about thinking and changing logic, quantitatively and qualitatively. The foundation of mathematics is reasoning [12]. The reason is a thought process that is carried out to conclude [13].

The National Council of Teachers of Mathematics, 2000, states that in the mathematics learning process, teachers must pay attention to five mathematical abilities: connection, reasoning, communication, problem-solving, and representation. It can be seen that mathematical reasoning ability is an aspect that must be developed in the mathematics learning process because it develops the main goal of learning mathematics in schools [14].

Reasoning ability is the goal in learning mathematics in schools, namely to train students in thinking and reasoning to conclude, which can develop problem-solving skills. It can develop abilities to convey information or communicate ideas orally, in writing, pictures, and graphics., maps, and diagrams [15]. Junior high school students can understand mathematical reasoning ability in making generalizations, compiling evidence, or explaining mathematical ideas and statements [16]. Mathematical reasoning ability must be developed. Reasoning ability can encourage students to manipulate mathematics to make generalizations, compile evidence, and explain mathematical ideas and statements so that reasoning abilities are needed to achieve mathematics learning outcomes [17]. 
SMP/MTS level students can master the reasoning ability in making generalizations, compiling evidence, explaining mathematical ideas and statements. Mathematical reasoning skills need to be developed to help students improve their abilities, not just remembering understanding abilities. The reality on the ground is not as expected. In general, teachers still teach mathematical concepts unidirectional and teacher-centered. Students feel lazy to learn mathematics because students think that learning mathematics is a boring lesson [18].

The 2002 Ministry of National Education stated that mathematics and reasoning are two things that cannot be separated because mathematical material is understood through reasoning. Reasoning can be understood and trained through learning mathematics [19]. Weak reasoning abilities can be seen from the Program For International Students Assessment (PISA) results in 2015, which placed 69 th out of 76 countries. The Trends International Mathematics and Science Study (TIMSS) report in 2015 measured the ability of 15-year-olds in reading literacy. Mathematics and natural sciences for the 8th-grade junior high school level, Indonesian students only rank 36 out of 49 countries in terms of performing scientific procedures with an average score of 356 mathematics, 403 science, and 397 reading [20].

Based on the research, it was concluded that the students' mathematical reasoning ability in the circle material was still lacking. Factors that caused this within students, namely interest in learning, the quality of students' reasoning abilities was only about $49 \%$ of the ideal score [21]. Research conducted by Aflch Yusnita, the population of all students in class IX and the sample as many as 30 people, shows a relationship between mathematical reasoning ability and the interest in learning of students who contribute or influence. Mathematical reasoning ability on interest in learning of SMP class IX students is $74.64 \%$ [22]. Based on observations and interviews conducted in class VIII of SMP Negeri 2 Banyubiru, information about the ability of students to solve story questions was still low. Students cannot understand the meaning of story problems and change story questions into mathematical models. Students are not able to conclude a problem. Students are not able to solve problems that use a lot of formulas. Most of the students do not like mathematics. This often happens because students perceive mathematics as a difficult subject to reduce learning interest. Students who think that mathematics is only a lesson that memorizes formulas [23]. Research conducted at Aisyiyah Private Mts, North Sumatra, has fairly good accreditation. The reasoning ability of students at the school in relation to and function is still not good. Many errors occur in answering questions about the material relations and functions because students do not see reason in the material. The location of students' ignorance in this material can be known by giving a test.

Based on the results of the author's interview with the mathematics teacher at SMP Negeri 16 Pekanbaru, showing the lack of student activity in learning, students have difficulty expressing mathematical ideas, the methods or learning models used by teachers are still traditional, where the teacher gives explanations in front of the class. Then students listen and take notes and are given assignments by the teacher. Furthermore, the researchers conducted a test to measure mathematical reasoning ability. Based on the test results on social arithmetic material, only about $45 \%$ of students scored above 75 , and $55 \%$ of students scored below 75 .

The indicators of students' mathematical reasoning abilities, according to Iman Kusmaryono, 2017 are (a) Identify the assumptions used and present them in the form of models (oral, written, pictures, or diagrams), (b) Determine the pattern of mathematical properties or symptoms to make generalizations (c) Perform mathematical manipulations (d) Check the validity of an argument (statement) [24]. 
Another aspect that needs to be considered in learning mathematics is learning. Interest is a feeling you get because you are related to something. Interest in something results from learning and tends to support learning activities [25]. Several factors, including mathematics, influence students' low mathematical reasoning ability is one of the subjects considered a difficult subject for students to learn mathematics. Interest in learning mathematics is an important factor that affects mastery of mathematical concepts, interest is very closely related to learning, learning without interest will feel boring. Students interested in learning activities will try harder than less interested students. High interest in a subject allows students to pay high attention to the subject so that it is also possible to have high achievement.

Another factor that causes the low value of students is interest in learning. This is indicated by students' attitudes who tend to be busy alone, chatting with friends, doing homework for other lessons, and paying less attention to ongoing learning. If students are given practice questions that are rather difficult, students do not work on these questions and are not interested in finding solutions to these problems. Students also lack a sense of responsibility for the teacher's tasks. In the process of learning mathematics, students are directed to be independent. To become independent, students must learn individually. Their interests will make students aware of the learning needs that must be carried out without any encouragement from others. Students interested in learning will continue to be diligent when studying, while students who do not have an interest in learning even though they want to learn will not continue to be diligent in learning. Therefore, interest in learning needs to be grown in students to achieve optimal learning outcomes and be responsible for their actions. As for the indicators of student interest in learning based on the Lestari (2018) and Sumarmo indicators in Hendriana (2017), The indicators in this study are: (a) Feelings of pleasure, (b) Attention, (c) Interest (d) Involvement [26].

Based on this explanation, interest in learning is very important to spur the development of students' thinking in learning mathematics. With the development of interest in learning, students can learn mathematics in various aspects of life because they are trained and accustomed to learning independently. Based on these things, this study aims to analyze the extent to which mathematical reasoning abilities are seen from the learning interest of junior high school students.

\section{METHODS}

In this study, the type of research used is descriptive qualitative research, which systematically analyzes and systematically describes the students' mathematical reasoning abilities when viewed from the students' learning interest in Social Arithmetic material [26]. The data of this research are in the form of written answers obtained from the results of written tests in the form of description questions. The subjects of this study were students of class VIII SMP Negeri 16 Pekanbaru, totaling 30 people. The objects used in this research are mathematical reasoning abilities and student learning interest questionnaires.

The data collection technique in this study is the test technique [27]. The research instrument used was a test instrument to measure students' mathematical reasoning abilities and a student learning interest questionnaire to measure students' interest in learning. The test instrument used to measure students' mathematical reasoning abilities consisted of 4 description questions adjusted to the indicators of reasoning ability [28]. While the student learning interest questionnaire was adopted from Hendriana, Rohaeti, and Soemarmo, students were asked to answer by tick (l) on one of the available answer choices. A Likert scale guides the scoring of each answer choice [29]. 
Table 1. Learning Interest Questionnaire Grid

\begin{tabular}{|c|c|c|c|c|}
\hline \multirow{2}{*}{ Indicator } & \multirow{2}{*}{ Information } & \multicolumn{2}{|c|}{ Statement } & \multirow{2}{*}{$\begin{array}{c}\text { Number of } \\
\text { Items }\end{array}$} \\
\hline & & Positive & Negative & \\
\hline Feeling happy & $\begin{array}{l}\text { - Student opinion about learning } \\
\text { mathematics } \\
\text { - Student's impression of math teacher }\end{array}$ & $3,4,5$ & $1,2,6$ & 6 \\
\hline Attention & $\begin{array}{l}\text { - Attention to learning math lessons } \\
\text { - Students' feelings during mathematics } \\
\text { learning }\end{array}$ & $8,10,11,12,13$ & $7,914,15$ & 9 \\
\hline Interest & $\begin{array}{l}\text { - Attention of students when discussing } \\
\text { math lessons } \\
\text { - Curiosity of students when participating } \\
\text { in mathematics learning }\end{array}$ & $16,18,19,22$ & $17,20,21$ & 7 \\
\hline $\begin{array}{c}\text { Student } \\
\text { Engagement }\end{array}$ & $\begin{array}{l}\text { - Acceptance of students when given } \\
\text { assignments/homework by the teacher } \\
\text { - Awareness about studying at home } \\
\text { - Student activities after and before } \\
\text { entering school }\end{array}$ & $24,25,26$ & 23,27 & 5 \\
\hline Total number & & & & 27 \\
\hline
\end{tabular}

Table 2. Mathematical Reasoning Ability Grid

\begin{tabular}{lll}
\hline \multicolumn{1}{c}{ Competence } & \multicolumn{1}{c}{ Mathematical Reasoning Ability Indicator } & About \\
\hline Reasoning & $\begin{array}{l}\text { Identify the assumptions used and present them in the form of } \\
\text { models (oral, written, pictures or diagrams) }\end{array}$ & 1 \\
Reasoning & $\begin{array}{l}\text { Determine the pattern of mathematical properties or } \\
\text { phenomena to make generalizations }\end{array}$ & 2 \\
Reasoning & $\begin{array}{l}\text { Perform mathematical manipulation } \\
\text { Reasoning }\end{array}$ & Assessing the validity or validity of a statement \\
\hline
\end{tabular}

Table 3. Category of Mathematical Reasoning Ability

\begin{tabular}{cc}
\hline Student scores & Ability Level \\
\hline $80<$ nilai $\leq 100$ & Very good \\
$60<$ nilai $\leq 80$ & Good \\
$40<$ nilai $\leq 60$ & Enough \\
$20<$ nilai $\leq 40$ & Not enough \\
$0<$ nilai $\leq 20$ & Very less \\
\hline & \\
Table 4. Criteria for students' & interest in learning \\
\hline Criteria for Student Interests & Information \\
\hline $\mathrm{x} \geq 89,34$ & Tall \\
$73,02<\mathrm{x}<89,34$ & Currently \\
$\mathrm{x} \leq 73,02$ & Low \\
\hline
\end{tabular}

\section{RESULTS AND DISCUSSION}

This research was conducted at SMP Negeri 16 Pekanbaru. The researcher made class VIII the subject of the research. The data needed in this study include the results of students' mathematical reasoning ability tests and student learning interest questionnaires processed for analysis. The following is the percentage of student answers presented in tabular form: 
Table 5. Results of Students' Answers on Indicator 1

\begin{tabular}{cccc}
\hline Student & Points Obtained in Question Indicator 1 & Score & Category \\
\hline S1 & 2 & 20 & Not enough \\
S2 & 4 & 40 & Enough \\
S3 & 2 & 20 & Not enough \\
S4 & 6 & 60 & Good \\
S5 & 2 & 20 & Not enough \\
S6 & 2 & 20 & Not enough \\
S7 & 2 & 20 & Not enough \\
S8 & 2 & 20 & Not enough \\
S9 & 2 & 20 & Not enough \\
S10 & 2 & 20 & Not enough \\
S11 & 2 & 20 & Not enough \\
S12 & 10 & 100 & Very good \\
S13 & 2 & 20 & Not enough \\
S14 & 2 & 20 & Not enough \\
S15 & 6 & 60 & Good \\
S16 & 6 & 60 & Good \\
S17 & 6 & 60 & Good \\
S18 & 6 & 60 & Good \\
S19 & 4 & 40 & Enough \\
S20 & 10 & 100 & Very good \\
S21 & 10 & 100 & Very good \\
S22 & 10 & 100 & Very good \\
S23 & 2 & 20 & Not enough \\
S24 & 2 & 20 & Not enough \\
S25 & 4 & 40 & Enough \\
S26 & 6 & 60 & Good \\
S27 & 6 & 60 & Good \\
S28 & 2 & 20 & Not enough \\
S29 & 2 & 20 & Not enough \\
S30 & 10 & 100 & Very good \\
\hline & & &
\end{tabular}

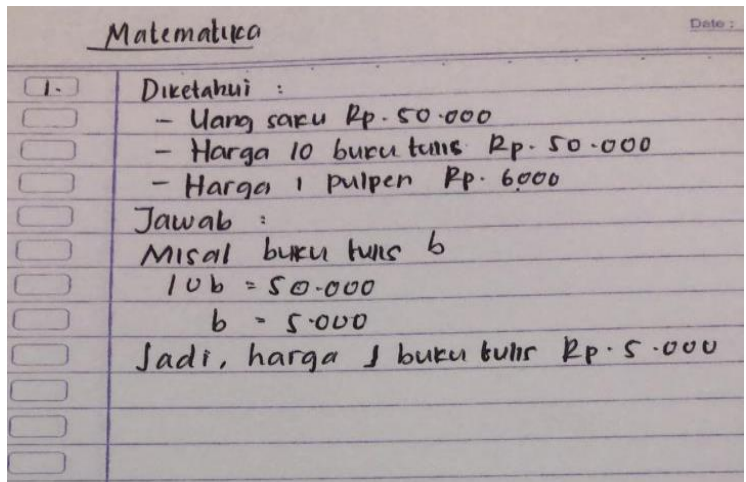

Figure 1. One of Student's Answer on Indicator 1

Based on the test results in the picture above, it can be seen that the mathematical reasoning ability on the indicators identifies the assumptions used and presents them in the form of models (oral, written, pictures, and diagrams) obtained results from 30 students of SMP Negeri 16 Pekanbaru, namely those who have very good mathematical reasoning abilities. As many as five people (16\%) have good mathematical reasoning ability, there are 7 people $(23 \%)$ who have sufficient mathematical reasoning ability there are three people $(10 \%)$ and have mathematical reasoning ability that is lacking as many as 15 people (50\%). 
Table 6. Results of students' answers on indicator 2

\begin{tabular}{|c|c|c|c|}
\hline Student & Points Obtained in Question Indicator 1 & Score & Category \\
\hline $\mathrm{S} 1$ & 2 & 13 & very less \\
\hline S2 & 2 & 13 & very less \\
\hline S3 & 5 & 33 & Not enough \\
\hline S4 & 5 & 33 & Not enough \\
\hline S5 & 5 & 33 & Not enough \\
\hline S6 & 5 & 33 & Not enough \\
\hline S7 & 5 & 33 & Not enough \\
\hline S8 & 12 & 80 & Very good \\
\hline S9 & 7 & 47 & Enough \\
\hline S10 & 7 & 47 & Enough \\
\hline S11 & 7 & 47 & Enough \\
\hline S12 & 15 & 100 & Very good \\
\hline S13 & 2 & 13 & very less \\
\hline S14 & 7 & 47 & Enough \\
\hline S15 & 5 & 33 & Not enough \\
\hline S16 & 10 & 67 & Good \\
\hline S17 & 12 & 80 & Very good \\
\hline S18 & 5 & 33 & Not enough \\
\hline S19 & 2 & 13 & very less \\
\hline S20 & 7 & 47 & Enough \\
\hline S21 & 10 & 67 & Good \\
\hline S22 & 12 & 80 & Very good \\
\hline S23 & 2 & 13 & Very less \\
\hline S24 & 15 & 100 & Very good \\
\hline S25 & 5 & 33 & Not enough \\
\hline S26 & 5 & 33 & Not enough \\
\hline S27 & 5 & 33 & Not enough \\
\hline S28 & 2 & 13 & very less \\
\hline S29 & 12 & 80 & Very good \\
\hline S30 & 10 & 67 & Good \\
\hline
\end{tabular}

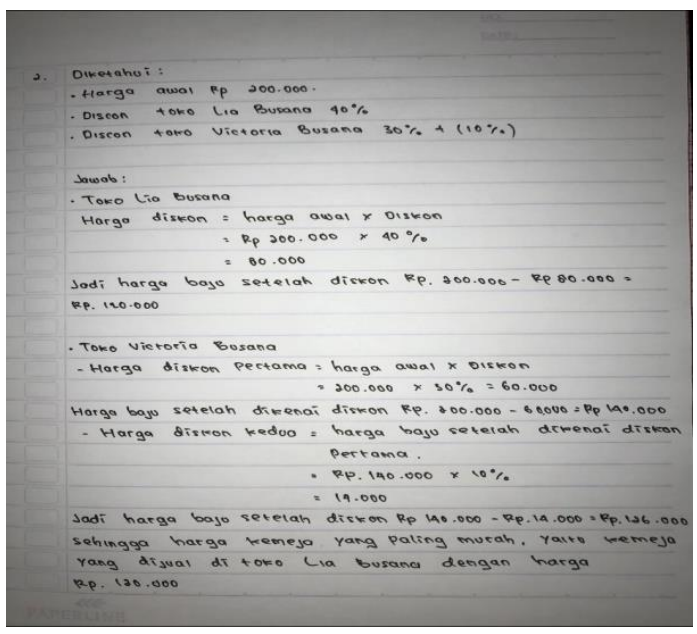

Figure 2. One of student's answer on indicator 2

Based on the results of the test above, it can be seen that the mathematical reasoning ability on the indicator Determining the pattern of mathematical traits or symptoms to make generalizations obtained results from 30 students of SMP Negeri 16 Pekanbaru, namely those who have very good mathematical reasoning abilities as many as six people $(20 \%)$, have reasoning abilities There are three 
good mathematicians $(10 \%)$, have sufficient mathematical reasoning ability as many as five people (17\%), have less mathematical reasoning ability as many as ten people $(33 \%)$ and have very poor mathematical reasoning ability as many as six people $(20 \%)$.

Table 7. Results of students' answers on indicator 3

\begin{tabular}{|c|c|c|c|}
\hline Student & Points Obtained in Question Indicator 1 & Score & Category \\
\hline $\mathrm{S} 1$ & 5 & 33 & Very less \\
\hline S2 & 0 & 0 & Very less \\
\hline S3 & 10 & 67 & Good \\
\hline S4 & 5 & 33 & Very less \\
\hline S5 & 15 & 100 & Very good \\
\hline S6 & 5 & 33 & Very less \\
\hline S7 & 5 & 33 & Very less \\
\hline S8 & 5 & 33 & Very less \\
\hline S9 & 5 & 33 & Very less \\
\hline S10 & 5 & 33 & Very less \\
\hline S11 & 5 & 33 & Very less \\
\hline S12 & 5 & 33 & Very less \\
\hline S13 & 15 & 100 & Very good \\
\hline S14 & 10 & 67 & Good \\
\hline S15 & 10 & 67 & Good \\
\hline S16 & 0 & 0 & Very less \\
\hline S17 & 0 & 0 & Very less \\
\hline S18 & 5 & 33 & Very less \\
\hline S19 & 10 & 67 & Good \\
\hline S20 & 0 & 0 & Very less \\
\hline S21 & 10 & 67 & Good \\
\hline $\mathrm{S} 22$ & 10 & 67 & Good \\
\hline $\mathrm{S} 23$ & 0 & 0 & Very less \\
\hline $\mathrm{S} 24$ & 10 & 67 & Good \\
\hline S25 & 5 & 33 & Very less \\
\hline S26 & 10 & 67 & Good \\
\hline $\mathrm{S} 27$ & 10 & 67 & Good \\
\hline $\mathrm{S} 28$ & 10 & 67 & Good \\
\hline $\mathrm{S} 29$ & 0 & 0 & Very less \\
\hline S30 & 15 & 100 & Very good \\
\hline
\end{tabular}

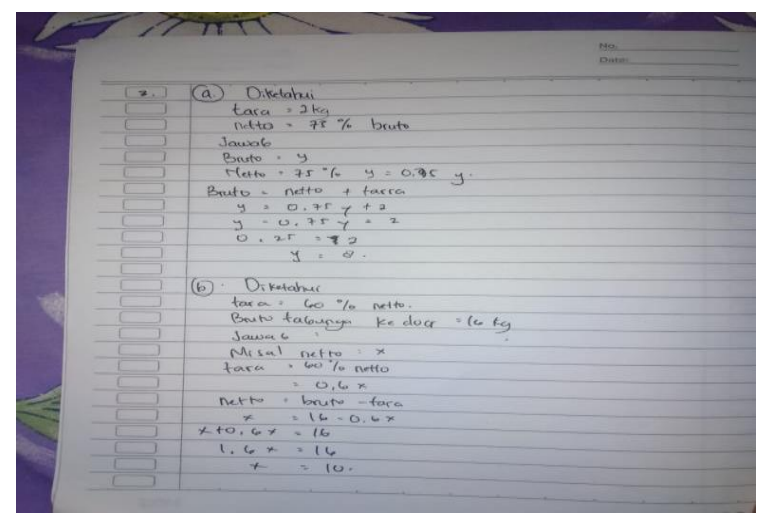

Figure 3. One of Student's Answer on Indicator 3

Based on the results of the test above, it can be seen that the mathematical reasoning ability on the indicator of Performing mathematical manipulation obtained results from 30 students of SMP Negeri 16 Pekanbaru, namely those who have very good mathematical reasoning abilities, there are 
as many as three people $(10 \%)$, having good mathematical reasoning abilities, there are as many as ten people $(33 \%)$, have sufficient mathematical reasoning ability there are 0 people $(0 \%)$, have mathematical reasoning ability that is lacking as much as one person (3\%) and has mathematical reasoning ability that is very lacking as many as 16 people $(53 \%)$.

Table 8. Results of Students' Answers on Indicator 4

\begin{tabular}{|c|c|c|c|}
\hline Student & $\begin{array}{l}\text { Points Obtained in } \\
\text { Question Indicator } 1\end{array}$ & Score & Category \\
\hline S1 & 4 & 40 & Enough \\
\hline S2 & 10 & 100 & Very good \\
\hline S3 & 2 & 20 & Kurang \\
\hline S4 & 9 & 90 & Very good \\
\hline S5 & 7 & 70 & Good \\
\hline S6 & 10 & 100 & Very good \\
\hline S7 & 5 & 50 & Enough \\
\hline S8 & 5 & 50 & Enough \\
\hline S9 & 5 & 50 & Enough \\
\hline $\mathrm{S} 10$ & 7 & 70 & Good \\
\hline S11 & 9 & 90 & Very good \\
\hline $\mathrm{S} 12$ & 10 & 100 & Very good \\
\hline S13 & 5 & 50 & Enough \\
\hline S14 & 9 & 90 & Very good \\
\hline S15 & 5 & 50 & Enough \\
\hline S16 & 0 & 0 & Very less \\
\hline S17 & 5 & 50 & Enough \\
\hline S18 & 5 & 50 & Enough \\
\hline S19 & 5 & 50 & Enough \\
\hline S20 & 5 & 50 & Enough \\
\hline S21 & 9 & 90 & Very good \\
\hline $\mathrm{S} 22$ & 9 & 90 & Very good \\
\hline $\mathrm{S} 23$ & 0 & 0 & Very less \\
\hline $\mathrm{S} 24$ & 9 & 90 & Very good \\
\hline $\mathrm{S} 25$ & 5 & 50 & Enough \\
\hline S26 & 5 & 50 & Enough \\
\hline S27 & 5 & 50 & Enough \\
\hline S28 & 10 & 100 & Very good \\
\hline S29 & 10 & 100 & Very good \\
\hline $\mathrm{S} 30$ & 5 & 50 & Enough \\
\hline
\end{tabular}

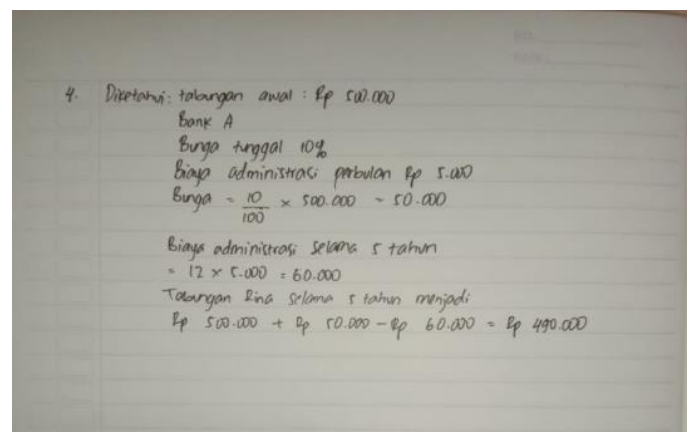

Figure 4. One of Student's Answer on Indicator 4

Based on the test results above, it can be seen that the mathematical reasoning ability on the indicator Assessing the validity or validity of a statement obtained results from 30 students of SMP Negeri 16 Pekanbaru, namely those who have very good mathematical reasoning abilities there are as many as 11 people (37\%), having good mathematical reasoning abilities. there are as many as two people (7\%), have sufficient mathematical reasoning ability there are 14 people (47\%), have 
mathematical reasoning ability that is lacking as much as one person (3\%) and has mathematical reasoning ability that is very lacking as much as two people $(7 \%)$.

Table 9. Overall Results of Answers for Students in Class VIII

\begin{tabular}{|c|c|c|c|c|c|c|c|}
\hline Students & Problem 1 & Problem 2 & Problem 3 & Problem 4 & Total score & Score & Category \\
\hline S1 & 2 & 2 & 5 & 4 & 13 & 26 & Not enough \\
\hline $\mathrm{S} 2$ & 4 & 2 & 0 & 10 & 16 & 32 & Not enough \\
\hline $\mathrm{S} 3$ & 2 & 5 & 10 & 2 & 19 & 38 & Not enough \\
\hline S4 & 6 & 5 & 5 & 9 & 25 & 50 & Enough \\
\hline S5 & 2 & 5 & 15 & 7 & 29 & 58 & Enough \\
\hline S6 & 2 & 5 & 5 & 10 & 22 & 44 & Enough \\
\hline S7 & 2 & 5 & 5 & 5 & 17 & 34 & Not enough \\
\hline S8 & 2 & 12 & 5 & 5 & 24 & 48 & Enough \\
\hline S9 & 2 & 7 & 5 & 5 & 19 & 38 & Not enough \\
\hline S10 & 2 & 7 & 5 & 7 & 21 & 42 & Enough \\
\hline S11 & 2 & 7 & 5 & 9 & 23 & 46 & Enough \\
\hline S12 & 10 & 15 & 5 & 10 & 40 & 80 & Good \\
\hline $\mathrm{S} 13$ & 2 & 2 & 15 & 5 & 24 & 48 & Enough \\
\hline S14 & 2 & 7 & 10 & 9 & 28 & 56 & Enough \\
\hline S15 & 6 & 5 & 10 & 5 & 26 & 52 & Enough \\
\hline S16 & 6 & 10 & 0 & 0 & 16 & 32 & Kurang \\
\hline S17 & 6 & 12 & 0 & 5 & 23 & 46 & Enough \\
\hline S18 & 6 & 5 & 5 & 5 & 21 & 42 & Enough \\
\hline S19 & 4 & 2 & 10 & 5 & 21 & 42 & Enough \\
\hline S20 & 10 & 7 & 0 & 5 & 22 & 44 & Enough \\
\hline S21 & 10 & 10 & 10 & 9 & 39 & 78 & Good \\
\hline S22 & 10 & 12 & 10 & 9 & 41 & 82 & Very good \\
\hline S23 & 2 & 2 & 0 & 0 & 4 & 8 & Very less \\
\hline S24 & 2 & 15 & 10 & 9 & 36 & 72 & Enough \\
\hline S25 & 4 & 5 & 5 & 5 & 19 & 38 & Not enough \\
\hline S26 & 6 & 5 & 10 & 5 & 26 & 52 & Enough \\
\hline S27 & 6 & 5 & 10 & 5 & 26 & 52 & Enough \\
\hline S28 & 2 & 2 & 10 & 10 & 24 & 48 & Enough \\
\hline S29 & 2 & 12 & 0 & 10 & 24 & 48 & Enough \\
\hline S30 & 10 & 10 & 15 & 5 & 40 & 80 & Good \\
\hline Amount & 134 & 194 & 200 & 189 & & & \\
\hline Average & 4,5 & 6,5 & 6,6 & 6,3 & & & \\
\hline Percentage & $15 \%$ & $22 \%$ & $22 \%$ & $21 \%$ & & & \\
\hline
\end{tabular}

Based on the test results above, it can be seen that the mathematical reasoning ability of the four indicators of students' mathematical reasoning ability was obtained from 30 students of SMP Negeri 16 Pekanbaru, for the first indicator, namely identifying the assumptions used and presenting them in the form of models (oral, written, pictures or diagrams), students able to answer question number 1 only 15\%, for the second indicator, namely Determining the pattern of mathematical properties or symptoms to make generalizations, students were able to answer question number 2 only $22 \%$, for the third indicator, namely Performing mathematical manipulation, students were able to answer the question number 3 only $22 \%$ and the fourth indicator, namely Checking the validity of an argument (statement), students were able to answer question number four only $21 \%$.

The data needed in this study includes a student learning interest questionnaire. The following are the results of the questionnaire which are presented in tabular form: 
Journal of Research on Mathematical Instruction, Vol. 2, No. 2, June 2021, $62-75$ jrmi.ejournal.unri.ac.id, Online ISSN: 2715-6869

Table 10. Results of Students' Learning Interest Questionnaire

\begin{tabular}{|c|c|c|}
\hline No & Students & Score \\
\hline 1 & S1 & 70 \\
\hline 2 & S2 & 94 \\
\hline 3 & S3 & 82 \\
\hline 4 & $\mathrm{~S} 4$ & 51 \\
\hline 5 & S5 & 92 \\
\hline 6 & S6 & 70 \\
\hline 7 & S7 & 72 \\
\hline 8 & S8 & 72 \\
\hline 9 & S9 & 51 \\
\hline 10 & S10 & 80 \\
\hline 11 & S11 & 70 \\
\hline 12 & S12 & 85 \\
\hline 13 & S13 & 70 \\
\hline 14 & S14 & 70 \\
\hline 15 & S15 & 82 \\
\hline 16 & S16 & 72 \\
\hline 17 & S17 & 70 \\
\hline 18 & S18 & 72 \\
\hline 19 & S19 & 68 \\
\hline 20 & S20 & 80 \\
\hline 21 & S21 & 92 \\
\hline 22 & S22 & 60 \\
\hline 23 & S23 & 81 \\
\hline 24 & S24 & 80 \\
\hline 25 & S25 & 70 \\
\hline 26 & S26 & 51 \\
\hline 27 & S27 & 84 \\
\hline 28 & S28 & 70 \\
\hline 29 & S29 & 70 \\
\hline 30 & $\mathrm{~S} 30$ & 70 \\
\hline
\end{tabular}

Table 11. Grouping of student interests high, medium and low

\begin{tabular}{cccccc}
\hline \multicolumn{5}{c}{ Grouping of Student Learning Interests } \\
\hline \multicolumn{2}{c}{ Tall } & \multicolumn{3}{c}{ Currently } & \multicolumn{3}{c}{ Low } \\
Student & Score & Student & Score & Student & Score \\
S-2 & 94 & S-3 & 82 & S-1 & 70 \\
S-5 & 92 & S-10 & 80 & S-4 & 51 \\
S-21 & 92 & S-12 & 85 & S-6 & 70 \\
& & S-15 & 82 & S-7 & 72 \\
& & S-20 & 80 & S-8 & 72 \\
& & S-23 & 81 & S-9 & 51 \\
& & S-24 & 80 & S-11 & 70 \\
& & S-27 & 84 & S-13 & 70 \\
& & & & S-14 & 70 \\
\hline
\end{tabular}




\begin{tabular}{ll}
\hline S-16 & 72 \\
S-17 & 70 \\
S-18 & 72 \\
S-19 & 68 \\
S-22 & 60 \\
S-25 & 70 \\
S-26 & 51 \\
S-28 & 70 \\
S-29 & 70 \\
S-30 & 70 \\
\hline
\end{tabular}

Based on the table, it can be seen that students' interest in learning mathematics at SMP Negeri 16 is very low, namely three people who have a high interest in learning, eight people who have a moderate interest in learning, while 19 people have a low interest in learning, so the teacher must provide motivation. A very large amount of learning supports students' interest in learning mathematics. It is proven that students' unsupportive interest in learning causes the low mathematical reasoning ability of SMP Negeri 16 Pekanbaru students.

\section{CONCLUSIONS AND SUGGESTIONS}

The analysis of the questionnaire data shows that the lack of asking for learning at SMP Negeri 16 Pekanbaru, only three students have a high interest in learning. These students have a moderate interest in learning as many as eight people, while others still lack in learning mathematics. Analyzing the test data showed that the students' mathematical reasoning ability, when viewed from a high learning interest, could work on the questions correctly if students who had moderate and low interest in learning could not do the questions correctly. Factors affecting students' mathematical reasoning abilities in terms of students' interest in learning are divided into internal and external factors: 1. Internal factors come from within the students themselves, such as the level of intelligence, attitudes, interests, talents and willingness, and self-motivation in learning mathematics. 2. External factors (outside students), namely environmental conditions around students. External factors that affect students' reasoning abilities are the learning process that is still teacher-centered, using an expository approach that dominates the process of class activities. In contrast, students are passive. Besides that, the exercises given are more routine questions so that they do not train reasoning power and thinking skills. Students only at a low level. As a result, students' understanding of mathematical concepts is low, and students tend to memorize mere concepts and procedures.

\section{REFERENCE}

[1] A. D. Putri and A. Yuliani, "Analisis Kemampuan Penalaran Matematis Siswa MA di Kabupaten Bandung Barat pada Materi Barisan dan Deret," J. Educ., vol. 1, no. 2, pp. 400-409, 2019.

[2] M. P. Azmi, "Penerapan Pendekatan Concrete-Representational-Abstract (CRA) Berbasis Intuisi Untuk Meningkatkan Kemampuan Komunikasi Matematik Siswa SMP," AKSIOMAJ. Progr. Stud. Pendidik. Mat., vol. 6, no. 1, pp. 68-80, 2017.

[3] M. Andriani and M. Hariyani, Pembelajaran matematika SD/MI. Pekanbaru: Benteng Media, 2013.

[4] S. Chotimah, "Upaya Meningkatkan Kemampuan Komunikasi Matematik Siswa Smp Di Kota Bandung Dengan Pendekatan Realistic Mathematics Educations Pada Siswa SMP di Kota Bandung," J. Didakt., vol. 9, no. 1, pp. 26-32, 2015. 
[5] R. Deswita, Y. S. Kusumah, and J. A. Dahlan, "Peningkatan Kemampuan Komunikasi Matematis Siswa Melalui Model Pembelajaran CORE dengan Pendekatan Scientific," Edumatika J. Ris. Pendidik. Mat., vol. 1, no. 1, pp. 35-43, 2018.

[6] BSNP, Salinan Lampiran Permendiknas Nomor 22 Tabun 2006 tentang Standar Isi untuk. Satuan Pendidikan Dasar dan Menengah. 2006.

[7] A. Fadillah, "Analisis Minat Belajar dan Bakat Terhadap Hasil Belajar Matematika Siswa," Mathline J. Mat. Dan Pendidik. Mat., vol. 1, no. 2, pp. 113-122, 2016.

[8] S. Isnaeni, L. Fajriyah, E. S. Risky, R. Purwasih, and W. Hidayat, “Analisis Kemampuan Penalaran Matematis dan Kemandirian Belajar Siswa SMP pada Materi Persamaan Garis Lurus," J. MEDIVES J. Math. Educ. IKIP Veteran Semarang, vol. 2, no. 1, pp. 107-116, 2018.

[9] Isrok'atun and A. Rosmala, Model-Model Pembelajaran Matematika. Jakarta: Bumi Aksara, 2018.

[10] Juhrani, H. Suyitno, and Khumaedi, "Analisis Kemampuan Komunikasi Matematis Berdasarkan Self-Efficacy Siswa pada Model Pembelajaran MEA,” Unnes J. Math. Educ. Res., vol. 6, no. 2, pp. 251-258, 2017.

[11] I. Kusmaryono, "Analysis of Narrative Mathematical Questions on Textbooks Based on Solo Taxonomy and Mathematical Power," Daya Mat. J. Inov. Pendidik. Mat., vol. 5, no. 3, pp. 299314, 2017.

[12] K. Jasija, F. A. Fitriana, and U. Aripin, "Pendekatan Realistic Mathematics Education Untuk Meningkatkan Kemampuan Komunikasi Matematis Siswa," JPMI Jurnal Pembelajaran Mat. Inov., vol. 1, no. 5, pp. 915-922, 2018.

[13] Nizam, Ringkasan Hasil-basil Asesmen Belajar Dari Hasil UN, PISA, TIMSS, INAP. Jakarta: Puspendik, 2016.

[14] H. Nurdiana, "Kemampuan Penalaran Matematis Ditinjau dari Minat Belajar," J. Pendidik. Mat. Semarang, vol. 1, no. 2, pp. 45-50, 2015.

[15] M. Ario, "Analisis Kemampuan Penalaran Matematis Siswa SMK Setelah Mengikuti Pembelajaran Berbasis Masalah,” J. Ilm. Edu Res., vol. 5, no. 2, pp. 125-134, 2016.

[16] B. Prasetyo and L. M. Jannah, Metode Penelitian Kuantitatif: Teori dan Aplikasi. Jakarta: PT Raja Grafindo Persada, 2009.

[17] D. Rachmayani, "Penerapan Pembelajaran Reciprocal Teaching untuk Meningkatkan Kemampuan Komunikasi Matematis dan Kemandirian Belajar Matematika Siswa," Pas. J. Math. Educ. J. Pendidik. Mat., vol. 2, no. 1, pp. 13-23, 2014.

[18] Riduwan, Skala Pengukuran Variabel-V ariabel Penelitian. Bandung: Alfabeta, 2011.

[19] S. Siregar, Metode Penelitian Kuantitatif: Dilengkapi dengan Perbandingan Perbitungan Manual \& SPSS. Jakarta: Kencana, 2013.

[20] Sugiyono, Metode Penelitian Pendidikan Pendekatan Kuantitatif, Kualitatif, dan R\&D. Bandung: Alfabeta, 2015.

[21] A. Shoimin, 68 Model Pembelajaran Inovatif dalam Kurikulum 2013. Yogyakarta: Ar-Ruzz Media, 2014.

[22] T. S. Sumartini, "Peningkatan Kemampuan Penalaran Matematis Siswa Melalui Pembelajaran Berbasis Masalah,” Mosharafa J. Pendidik. Mat., vol. 4, no. 1, pp. 1-10, 2015.

[23] T. R. Suprihatin, R. Maya, and E. Senjayawati, "Analisis Kemampuan Penalaran Matematis Siswa SMP Pada Materi Segitiga dan Segiempat," JKPMI J. Kaji. Pembelajaran Mat., vol. 2, no. 1, pp. 9-13, 2018.

[24] R. Ahmadi, Pengantar Pendidikan. Yogyakarta: Ar-Ruzz Media, 2014.

[25] C. Saiz and S. F. Rivas, "New Teaching Techniques to Improve Critical Thinking. The Diaprove Methodology," Educ. Res. Q., vol. 40, no. 1, pp. 3-36, 2016.

[26] Pemerintah Republik Indonesia, Salinan Lampiran Undang-Undang No 20 Tabun 2003 tentang Sistem Pendidikan Nasional. 2003.

[27] A. Yuliani, "Meningkatkan Kemampuan Komunikasi Matematik Pada Mahasiswa Melalui Pendekatan Contextual Teaching and Learning (CTL)," Infin. J., vol. 4, no. 1, pp. 1-9, 2015.

[28] Z. Amir and Risnawati, Psikologi Pembelajaran Matematika. Yogyakarta: Aswaja Pressindo, 2016. 
Journal of Research on Mathematical Instruction, Vol. 2, No. 2, June 2021, $62-75$

jrmi.ejournal.unri.ac.id, Online ISSN: 2715-6869

[29] M. Zein, Evaluasi pembelajaran matematika. Pekanbaru: Daulat Riau, 2012.

\section{BIOGRAPHY}

Dewi Yuliani

She was of Pekanbaru on Juni 06,1997. The reearcher completed her bechelor Strata S2 in the University of Riau. Phone 0922-8494-9940 and email: dewiyuliani1997@gmail.com. 